\title{
Islam and Local Wisdom in Indonesia
}

\author{
Dinar Fatmawati \\ Brawijaya University, Indonesia \\ Email: dinarachmad19@gmail.com
}

\begin{tabular}{l} 
ARTICLE INFO \\
\hline Date Received: 29 November \\
2020 \\
Revision Date : 16 December \\
2020 \\
Date Received : 07 January 2021 \\
Keywords:
\end{tabular}

Keywords:

Islam; The community; Local;

Good Behavior; Regional;

\begin{abstract}
Local wisdom is knowledge that can be from the local community that applies to a particular area and will be different from one area to another in the way it applies. Local wisdom is evidence of an existence of the behavior of local people who show the color of behaviors that contain values, norms, customs, have a wise nature, wise, and good value. mutually agreed upon in a particular place.
\end{abstract}

Coresponden Author:

Email: dinarachmad19@gmail.com Article with open access under license

\section{INTRODUCTION}

Islam is the majority religion in indonesia, and we know that the country is made up of various tribes and cultures that live in society, it is in accordance with article 28J, paragraphs 1 and 2, which states that everyone must respect the human rights of others in the life of the people, nation, and state in an orderly manner, while still subject to restrictions on the restrictions of legislation that aims to guarantee and respect the rights of others in order to fulfill the sense of justice with justice. consider morals, religious values, security, and public order.

Based on these provisions Islam and local wisdom can run together. And of course will give influence to each other, in a reciprocal way, Islam that adjusts to local wisdom and local wisdom that will adjust to the wisdom of Islam.

There is no interest between each of them to be favored except just to live the life of the nation and state that is aligned between Islam and local wisdom. With a variety of local wisdom that lives in indigenous peoples in Indonesia, increasingly provides a lot of cultural diversity in the country of Indonesia.

\section{METHOD}

The method uses descriptive research. According to Hadari Nawawi (2002: 63), descriptive research is a research whose problem solving procedures are investigated by describing or describing the state of the subject or object of research (a person, institution, society, and others) at this time based on facts that appear as including data interpretation and data analysis.

This research is included in descriptive research because it is intended to know the main problem of Islamic values of local wisdom in Indonesia for the development of general principles of good governance.
The approach used in this research is an approach with qualitative methods. Qualitative approach is an approach that intends to understand phenomena about what the research subjects experience such as behavior, perception, motivation, action, and others, holistically and by way of description in the form of words and language, in a natural context and by utilizing various natural methods (Lexy J. Moleong, 2005: 6). From the implementation of qualitative method approach procedures it will produce descriptive data in the form of written or spoken words from people and observable behavior. A qualitative approach is expected. able to produce an in-depth description of the speech, writing and or observable behavior of an individual, group, community, and or an organization in a particular context setting that is studied from a whole, comprehensive, and holistic point of view (Basrowi Suwandi, 2008). Based on the above understanding, this research method is intended to describe and elaborate on the Islamic values of local wisdom that have been implemented in Indonesia, the values of local wisdom in Indonesia that can be raised in the development of general principles of government management, and supporting factors and inhibitions.

\section{RESULT AND DISCUSSION \\ Understanding Local Wisdom}

Local wisdom is part of a community's culture that is inseparable from the language of the community itself. Local Wisdom. It is usually passed down through generations through word of mouth. Local wisdom exists in folklore, proverbs, songs, and folk games. Local wisdom as a knowledge found by certain local communities through a collection of experiences in trying and integrated with an understanding of the culture and natural state of a place. 
In the research conducted by Al-Musafiri, Utaya, and Astina (2016) mentioned that local wisdom has a role to reduce the impact of globalization by instilling positive values in youth. The planting of these values is based on the values, norms and customs owned by each region.

According to (Sibarani, 2012), local wisdom is a form of original knowledge in the community derived from the noble value of local culture to regulate the order of people's lives or it is said that local wisdom.

Local wisdom comes from 2 two words, namely wisdom which means wisdom and local means local area. In general, the understanding of local wisdom is the ideas, values or views of a place that has a wise nature.

The definition of local wisdom is a theme that discusses the humanities used to restore a civilization from a crisis of modernity. Local wisdom is favored as a true knowledge where dealing with a standard of modern science that is knowledge obtained through the approach of positifism, which is a way of preparing knowledge through observation of symptoms to seek its laws. Modern science or called modern science is considered to manipulate nature and culture, by objectifying all facets of natural and inner life with the consequences of loss of elements of value and morality, in the understanding of modern science elements of value and morality are considered as irrelevant elements in understanding science.

Local specifically points to limited interaction space with a limited value system as well. As an interaction space that has been designed in such a way that involves a pattern of relationship between human and human or human with its physical environment. The pattern of interaction that has been designed is called settting. Setting is an interaction space where one can arrange face to face relationships in their environment. A life setting that has been formed directly will produce values. Those values will be the foundation of their relationship or a reference to their behavior.

The form of local wisdom is manifested in 2 aspects, namely: real-life local wisdom (Tangible), including: Textual, some types of local wisdom such as value system, procedure, special provisions, which are poured into the form of written notes as found in the traditional primbon book, calendar, prasi or writing culture on lontar leaf sheets, in the form of buildings / architecture, nature reserve objects / Traditional (artwork), such as Kris, batik, and so on. The second is intangible local wisdom, where local wisdom is like verbal and hereditary advice that is biased in the form of chants and songs containing traditional teaching values. Through advice or other forms of intangible Local wisdom, social values are conveyed orally/verbally from generation to generation.
Local wisdom is an explicit knowledge that emerges from a long period and evolves together with the community and the environment in the area based on what has been experienced. So it can be said that local wisdom in each region differs depending on the environment and their needs.

Local wisdom is a form of aseli knowledge in the community that comes from the noble value of local culture to regulate the order of life of local people. (sibarani 2012), local wisdom is part of a culture that can be used to reduce the influence of globalization based on the values, norms, and customs that each region has (Al musafitri, Utaya, and Astina), local wisdom is local ideas that are wise, full of wisdom, good value, that are embedded and followed by members of the community. (sartini 2004), local wisdom is human intelligence possessed by certain ethnic groups gained through community experience. This means that local wisdom here is the result of certain communities through their experience and not necessarily experienced by other communities. (Rahyono, 2009). Local wisdom is a knowledge based on the experience of people hereditary between generations. This knowledge becomes the rule for people's daily activities when it comes to family, neighbors, other communities, and the surrounding environment. (phongphit and Nantasuwan). Local wisdom is a conceptual idea that lives in the community, grows and develops continuously in the public consciousness, serves in regulating people's lives from the sacred to the profane.

\section{Function of Local Wisdom}

In local wisdom will always be contained called values, norms, customs, have a wise nature, arif, and good value. This means that values, norms are interconnected because all of them try to direct good mindsets, attitudes, behaviors. Similarly, ethics and morals have almost the same understanding / related, because both contain values and norms with the aim of regulating human behavior, which refers to the prevailing habits in the local wisdom community in Indonesia.

Some local wisdom in Indonesian society, including the following, Forest Prohibition Adat (Rumbio village, Kampar District, Riau Province), local wisdom is made with the aim that the surrounding community together preserve the forest there, where there is a regulation should not cut down trees in the forest and if violated will be subject to fines such as $100 \mathrm{~kg}$ of rice or money of $6,000,000$ rupiah. Bebie (Muara enim- South Sumatra) is a tradition of planting rice and harvesting together with the aim that rice harvesting is completed quickly, and after the harvest is finished there will be a celebration as a form of gratitude for a successful harvest. Another local wisdom is to breathe katungkul ku pati, paeh teu nyaho in prey (everything has its limits, including natural resources and the environment). Kudu inget 
ka Bali geusan ngajadi (human beings part of nature, must love nature, inseparable from nature).

Local wisdom is the basis for policy taking at the local level in the fields of health, agriculture, education, natural resource management and rural community activities. In local wisdom, local cultural wisdom is also contained. Local cultural wisdom itself is local knowledge that has been so integrated with the belief system, norms, and culture and expressed in traditions and myths embraced over a long period of time.

Function of Local Wisdom, Local wisdom serves for the conservation and preservation of natural resources, local wisdom serves to develop human resources, serves as the development of culture and science, serves as advice, belief, literature and abstinence.

\section{Settings About Local Wisdom}

Local wisdom is a characteristic that legally lives in the community, so that the local wisdom that is part of the indigenous law community gets further regulation in the Constitution of 1945, which is contained in article $18 \mathrm{l}$ paragraph 2 which is written.

"The state recognizes and respects the national unity of customary law and its traditional rights as long as it is alive and in accordance with the development of society and the Principles of the Unitary State of the Republic of Indonesia, which are regulated in the law."

\section{Forms of Local Wisdom}

Local wisdom consists of six dimensions, namely: First, Local Knowledge. Every community anywhere in the countryside and inland always has local knowledge related to their environment. Local knowledge is related to changes and cycles of drought and rainy climates, types of fauna and flora, and geographic, demographic, and sociological conditions. This happens because people inhabit an area for a long time and have undergone various social changes causing them to be able to adapt to their environment. This adaptability becomes part of their local knowledge in conquering nature. Second, Local Values. To manage the shared life between the citizens, each community has local rules or values that are adhered to and mutually agreed by all its members. These values usually regulate the relationship between man and man, man and nature and man with his God. These values have a dimension of time, the value of the past, the present and the future, and these values will change according to the progress of their society. Third, Local Skills, that is, the survival ability of each community can be met if the community has local skills. Local skills from the simplest such as hunting, concocting, farming to creating a household industry.

These local skills are usually only sufficient and able to meet the needs of their respective families or called subsistence economies. These local skills are also life skills, so these skills are very dependent on the geographical conditions of the place where the community lives. 4th, Local Resources. these local resources are generally natural resources that are un up-to-date and renewable resources. The community will use local resources according to their needs and will not be massively or commercialized. These local resources have been divided into areas such as forests, gardens, water sources, agricultural land, and settlements, ownership of these local resources is usually collective or communitarian. Fifth, local decision making mechanisms. According to indigenous and cultural experts, each community has its own local government or so-called tribal government. A tribe is a legal entity that rules its citizens to act as citizens. Each community has different decision-making mechanisms. There are communities that do democratically or "sit equally low standing equally high". There are also communities that do in stages or tiered up and down (Morley \& Ife, 2002).

The form of local wisdom can be categorized into two aspects, namely local wisdom that is tangible and intangible. First, Tangible, the form of real local wisdom includes the following aspects: First, textual of some types of local wisdom such as value systems, ordinances, special provisions that are poured into the form of written notes as found in the traditional primbon, calendar and prasi (culture written on lontar leaf sheets). For example, prasi, physically, consists of writing parts (story scripts) and drawings (illustrated drawings). second, many traditional buildings are a reflection of local wisdom, such as people's house buildings in Bengkulu. This people's house building is a residential building that is built and used by most people with reference to the house of the customary chairman. This vernacular building is unique because of the development process that follows the ancestors, both in terms of knowledge and methods (Triyadi, Sudradjat, \& Harapan, 2010). This vernacular building does not appear to be fully supported by the principles and theories of adequate buildings, but in theory proved to have local potentials because it was built through a trial \& error process, including in addressing environmental conditions. Cultural Heritage Objects / Traditional (Artwork) many cultural heritage objects that are one form of local wisdom, for example, kris. Kris is one of the most important forms of cultural heritage. Although at this time the kris is facing various dilemmas in development as well as in contributing the goodness contained in it to the values of humanity on this earth, the organization of education and culture or UNESCO United Nations Agency, confirmed the Kris Indonesia as a masterpiece of cultural heritage belonging to all nations in the world. At least since the 9th century, as a cultural dimension, Keris not only serves as a means of martial arts, but is often a medium of artistic expression in terms of concepts, 
forms, decorations to meanings contained in aspects of art and tradition of archeometalurgical technology. Kris has a function as a symbol art when viewed from the aspect of art and is a symbol of the message of the owner of the creator.

Another illustration is batik, as one of the handicrafts that has high artistic value and has been a part of Indonesian culture (especially Java) for a long time. There are various kinds of batik motifs that each of these motifs has its own meaning. The touch of cultural art depicted in batik is not only a picture painting, but has the meaning of the previous ancestors, such as religious mirroring (Hindu or Buddhist), social and cultural values inherent in people's lives.

Second, intangible, in addition to the form of tangible local wisdom, there is also a form of intangible local wisdom such as verbal and hereditary advice that can be in the form of chants and songs containing traditional teaching values. Through advice or other forms of intangible local wisdom, social values are conveyed orally/verbally from generation to generation. Examples of local wisdom of the community (Elly Burhainy Faizal) exemplify some of the richness of culture, local wisdom in the archipelago related to the utilization of nature that deserves further excavation of its meaning and function and its current and future conditions. Local wisdom is found in some areas: Papua, there is a belief te aro neweak lako (nature is me). Mount Erstberg and Grasberg are believed to be the head of the mama, the land is considered part of human life. Thus, the use of natural resources carefully. Serawai, Bengkulu, there is a conviction celako kumali. Environmental sustainability is manifested from the strength of this belief, namely the taboo values in farming and the tradition of planting climbs. Dayak Kenyah, East Kalimantan, there is a tradition of tana' ulen. Forest areas are controlled and belong to indigenous peoples. Land management is regulated and protected by customary rules. People of Undau Mau, West Kalimantan. This community develops environmental wisdom in the pattern of structuring residential space, by classifying forests and utilizing them. Farming is done by rotation by setting the period of bera, and they know the taboo so that the use of technology is limited to simple and environmentally friendly agricultural technology. Kasepuhan Pancer Pangawinan Community, Kampung Dukuh, West Java. They know traditional ceremonies, myths, taboos, so the use of forests is careful. No exploitation except with customary elders' permission. Bali and Lombok, people have awig-awig.

Local wisdom is a conceptual idea that lives in the community, grows and develops continuously in the public consciousness, serves in regulating people's lives from the sacred to the profane.

Characteristics of Local Wisdom
Characteristics of local wisdom among the ability to control, is a fortress to survive the influence of outside culture, has the ability to accommodate outside culture, has the ability to give direction of cultural development, and has the ability to integrate or unite outside culture and aseli culture. The characteristics of Local Wisdom are able to survive against outside cultures, have the ability to accommodate elements of outside culture, have the ability to integrate outside cultural elements into indigenous cultures, have the ability to control, be able to give direction to cultural development.

Islamic View of Local Wisdom.

Islam is a religion, if religion is studied separately, then religion can be seen from the origin of its growth according to the views of the general public that is influenced by Western thought to include various beliefs born through human ideas, thoughts, or ideas in the form of culture and religion born from revelation. Western thinkers often equate religions born of cultures and religions born of revelation. While the two things are religions born from culture and religion born from the revelation contains very important differences and at the same time contains very different implications.

In the Qur'an, religion is referred to as Millah, an example of Millatu Ibrahim which means the religion of Ibrahim. Al-Nahl: 123. In addition, in the Qur'an religion is also called din or al-din. For example: lakum dinukum waliya din which means to you din (religion) you, and to me din (religion) me. (Al-Kafirun: 6). Besides meaning religion, the word din also means: vengeance on the Day of Resurrection, customs, laws, regulations, and obedience.

Religion is a value system that is recognized and believed to be true and is the path to the salvation of life. As a value system, religion covers 3 (three) main issues, namely: first the belief system or credo, which is part of the most basic religion in the form of belief in the existence of supernatural powers, Dzat the Absolute One outside human life. Second, the system of worship or rites, namely human behavior and deeds in relation to Dzat which is believed to be a consequence of the belief in the existence of the Almighty Dzat. Third, the rules, rules or norms that govern human relationship with human beings, or humans with other nature in accordance with these beliefs and worship. (Thohir Luth, 2005).

Religion contains 4 (four) kinds of elements (Hafidy, 1982): First, it is a way of life, a concrete muamallah way. Religion has certain rules as guidelines for the life of its adherents. Second, it teaches the belief of the One True God. God is impossible, and there are no numbers. Third, it has a book which is a collection of revelations received by the Prophet from the One True God, by whispering the Holy Spirit (The Angel Gabriel). Fourth, led by a Prophet. If the Prophet is still alive, 
he is not hidden in the environment of a foolish layman, but spread his teachings openly, and able to discuss in the midst of a smart person. And if the Prophet had died, there would have been clear evidence that he had lived, saying this and that was for the guidance of his people.

Judging by its nature and source, religion can be classified into 3 (three) categories. That is, first, the religion of revelation and religion is not revelation. Second, missionary religion and religion are not missionaries. Third, religious race geographically and universal religion. The religion of revelation is a religion that desires faith in the Lord of Revelation, to the Messengers of revelation and to the books of revelation and its message to all mankind. While religion is not a revelation, it does not view submission to God and obeylng His rules as essential. The differences between the two types of religions are stated by Al-Masdoosi in Leaving Religious of the world, in 8 definitions: First, the religion of revelation is based on the concept of god's oneness, whereas religion is not revelation is not so. Second, the religion of revelation believes in the Prophet, while religion is not a revelation does not believe in the Prophet. Third, in the religion of revelation the main source of good and bad guidance is the revealed scriptures, whereas religion is not a revelation to argue that scripture is not important. Fourth, all religions of revelation are born from the Middle East, while religion is not a revelation born from a non-Middle Eastern country. Fifth, the religion of revelation was born in areas of the semitic race (semitic religions are religions of revelation, such as Islam, Christianity, and Judaism, while non-semitic religions, namely Aryans, and Mongolians are not religions of revelation, such as Hinduism, Buddhism, Zoroaster in Mongolia, or Confucianism, Taoism, and cytoism in Mongolia. Non-semitic religions according to their teachings include geographical race or local religion and semitic religions are more universal. However, when viewed from the essensi teachings only Islam is Universal. Although in later developments all religions expressed their universality. And if seen from the source, religion is divided into categories samawi (religion of the sky) and religious culture (ardil). While those who fall into the category of samawi religion is only Islam.). Sixth, the religion of revelation in accordance with its teachings is missionary, while religion is not a revelation not a missionary religion (missionary religion is a religion that according to its teachings should be spread to all mankind, and non-missionary religion there is no obligation in its teachings to spread to all mankind. And in this category the religion that seems clear message to be spread is Islam, but in the next development the people of religions other than Islam turn the message into a missionary religion). Seventh, the religious teachings of revelation are clear and unequivocal, while religious teachings are not vague and elastic revelations. Eighth, the religion of revelation gives a clear and complete direction both spiritual and material aspects, while religion is not a revelation more focused on the spiritual aspect alone, such as to Taoism, or on material aspects such as confucianism.

The importance of religion for human beings is a natural need (fitrah) of man. Various opinions from figures about the religious physic can be studied from some experts through his thinking. For example, Einstein warned that social nature is one of the driving factors for the realization of religion. Man witnessed death take away his father, his mother, his relatives and great leaders. He took them one by one, so that people felt lonely when the world was empty. So the hope of something that can guide and direct, the hope of being lovers and loved, the desire to rely on others and regardless of feelings of despair, all of it forms within one's own psychiatric basis to accept faith in God. William James, a German philosopher, stated that while it is true that physical and material things are the source of the growth of various inner desires, there are also many desires that grow from nature behind this material realm. In fact, many human actions do not correspond to material calculations. In every circumstance and religious act, we can always see various forms of nature such as sincerity, sincerity, longing, friendliness, love, and sacrifice. Psychiatric symptoms of a religious nature have a variety of personalities and characteristics that are not in harmony with all the common symptoms of the human psyche.

In Arabic Islam is "salam", which means "safe", is a religion that believes in one god namely Allah. Etymologically the word Islam is derived from the meaning of the same word as the word "salam" which means also "peace". So for people who embrace Islam the word means "person who submits to Allah" in Indonesian.

Islam brought by Muhammad SAW, in each teaching teaches the value of spritual value that can enlighten the world and the whole, that Islam is present on this earth as a source of mercy for the universe, the guidance of Islam contains light including the light of salvation (the hereafter), the light of holiness (belief), the light of peace, the light of harmony, the light of outward and inner wellbeing.

In culture, the role of the Prophet Muhammad SAW, recognized by all circles, both Muslims and non-Muslims. He with his teachings derived from Allah SWT, The Lord of Hosts produces a civilization that is the most glorious and highest in history, a very large appreciation of the science of yearling, provides clear limits in creation so as not to damage the purity of the human soul, and fertilize the Truth of Islamic teachings naturally is not indisputable by any measuring instrument, anytime, and anywhere. The relevance of Islamic truth can 
be proven in various segmentations of modern world life. The result is not obtained from any teachings carried by Muhammad SAW, a gap there are shortcomings in it, but can always be compatible with everything that is absolutely true. Throughout the history of Rasulallah Muhammad SAW occupied the highest position and the most influence for the formation of human civilization. Civilization itself has meaning in relation to human society. Often the term is used to refer to a "complex" society: characterized by practices in agriculture, works and settlements, compared to other cultures, members of a civilization will be organized into complex divisions of labor within the structure of social hierarchies.

Civilization has a broader meaning than culture that can be interpreted as a manifestation of community participation in the form of art, customs, customs, beliefs, values, behavioral materials, habits in tradition, which is a way of life of society. For the author, Civilization can be one of the formations that began from the existence of local wisdom.

The concept of peace is always related to human beings (society) who always aspire to a relationship based on a peace, the relationship between human beings with each other can be called as the concept of brotherhood of fellow human beings (ukhuwah insaniyah) based on the teaching that all mankind is a creature of God. Although Allah gives guidance of truth through the teachings of Islam, but Allah also gives freedom to every human being to choose the way of life based on consideration of the ratio. Therefore from the very beginning of creation, God did not establish man as one people, whereas God could if he wanted to. That is the nature of man, as Allah explains in the Qur'an (Al-Maidah: 48); "If Allah had so willed, He would have made you a people, but God would have tried you for His gift to you".

The principle of freedom hinders the coercion of a religion by any human authority, even the Apostle is forbidden to do so, as God says in the Quran (Jonah: 49)

"And if your Lord had so willed, all those who were on earth would have believed in it all. Do you compel people to become believers?"

Tensions that often arise internal religious people, and between religious people come from, the nature of each religion that contains the duty of da'wah or mission, the lack of knowledge of the religion itself and the religion of other parties, the believers are not able to restrain themselves, so the lack of determination on the person who makes the decision (Aqidah), and the faith in the view of religion is about a belief and not an act. What has become the determination of one's heart for sure whether it is right or wrong is referred to as faith. The pure is the basic foundation for the establishment of Islamic society.
Talking about local wisdom is also in accordance with the elements that can be briefly summarized as a wise behavior of local people inseparable from the elements of moral, ethical, moral, value, which is also called good behavior. So it is not superfluous if in Islam is referred to as morality. In Arabic, jama' from "khuluqun" which means ethics. (Thohir Luth:2005). The word "morality" corresponds to "Khalqun" (creation), and is closely related to khaliq and makhluq. Every human act and behavior (makhluq), both individually and socially, cannot be separated from the supervision of khaliq (God). This word is derived from the sentence stated in the Qur'an Surah AlQalam verse 4: "Indeed you (O Muhammad) have noble ethics." Similarly hadith of the Prophet SAW: "I was sent to perfect the glory of ethics."

Local wisdom that contains many elements of moral elements, ethics, values, which can be described as a condition of good behavior is, is a satisfaction for us if others can live decently as we are despite the way through our help. Because that's where our happiness lies because others can be happy as we are, such cultures need to be ideals and obsessions to build a common good in the sense of mutual care, fostering each other, loving each other for the common good. It is this cultural bond that becomes the glue in building the harmonization of the lives of others without any injuries. building a marhamah society, namely each other's affection in kindness. Namely each other's affection in kindness, then the concept of sharing kindness is the entrance to the marhamah society, where there is a reality to help each other become an integral part of the activity of all of us, if this is the case then we can claim that among the richest people is us who are always willing to share the good, namely in the sense of give and give. It's not take and give as it used to be. How rich people are who always give and give in their lives, because they have instilled a lot of good. Look at the word of God: "The likeness of those who spend their wealth in the way of Allah is as the likeness of a seed that grows seven ears, in every grain a hundred grains. Allah multiplies (the reward). To whomsoever $\mathrm{He}$ wills, and Allah is All-Knowing, All-Aware. AlBaqarah:261). (Prof.Thohir Luth: Sharing Kindness).

Human beings present on this earth cannot live individually, humans are essentially social beings. One small example is when we cannot get food once for one day, then we will hope that there will be others who feed us or at least feed us when we need it. Therefore man will not be able to live alone. People will be gathered into a society and will need each other.

This facet of life arranged by God can be grouped into two groups. First things related to human relationship with its creator (worship / to maintain the relationship between God and His 
servants), and the relationship between man and other human beings and the surrounding nature.

In a local wisdom that will later form a culture and give birth to a new civilization. Of course Islam will be very flexible in coexisting with local wisdom and Islam will always be acceptable anywhere. In the Islamic country even though in everyday life is not with the sound of adhan (call to prayer time), we know that Islam in the country is a minority but Islam can still carry out its activities normally. Similarly, in Hongkong there is a place that has always been called the Islamic Center. That means a group of Islamic people can carry out their activities. If we look at Islam with local wisdom prevailing in Indonesia then Islam will be able to coexist in harmony with local wisdom even more than that then Islam can also be a discourse as well as a reliable filterization and able to realize good in accordance with the meaning of local wisdom itself.

We know wayang kulit is a culture born from Java, a scene that is a favorite of local indigenous peoples can bring a story of Islamic travel that we can categorize the form of local wisdom in oral form.

7 moral characteristics (Al-Qardhawy, 1997) namely: first, reasoned morals (argumentative) and understandable, namely Islamic morals regardless of the absolute ritual habits of dogmatic, known by the Jewish religion, and which some researchers assume about morals as a direct consequence for the language of da'wah to morals in all religions, but they do not know that Islam is precisely the opposite of that. Indeed, Islam has always relied on logical judgments and arguments that are acceptable to a straight mind and a healthy instinct, namely by explaining the maslahat (goodness) behind what He commands and the damage from what He prohibits. It is mentioned in Surah Al-Ankabut:45 "and establish prayer. Indeed prayer forbids indecency and evil". and understandable, second, universal morals, namely morals in Islam based on a universal human character, namely the prohibition for a human race applies also to other races, even Muslims and other peoples are the same before the universal morals of Islam. In the Qur'an Surah IMaidah:8, God mentions: "and do not hate a people once, encouraging you to be unjust. And if you are in a city, then know that Allah is All-Er, All-er, All-er.

Thus the ethics (morals / morals) of Islam is free from all tendencies of national, tribal and class racism. third, conformity with fitrah, which means Islam comes to bring what is in accordance with the fitrah and human nature and perfect it. Islam recognizes the existence of man as God has created with all his psychiatric impulses, fitrah tendencies and everything he has outlined. Islam makes the start of creating legal boundaries for him in order to maintain the good of society and individual human beings themselves.

Islam allows people to enjoy good things or things (sustenance), jewelry and legalizing personal ownership. But Islamic shari'a does not justify instinct if things and things are unclean or are immoral. The Word of Allah Al A'raf: 32

Say, "Who hath foreho has fores mercy on ornaments from Allah which He has brought forth for His servants, and (whosoever forbids) good provision?".

Islam with all that it is allowed to maintain human nature has put the concept of rules and restrictions neutral or moderate, excessive and extreme attitudes will lead to a despicable animal war. fourth, pay attention to reality, meaning that among the moral characteristics of Islam is a realistic morality, does not issue its commandments and prohibitions to people who live in "ivory towers" or people who fly hovering in the awang-awag idealism, but rather instructs people who have impulses and passions, desires and ideals, interests and needs, also have a biological tendency and desire for worldly pleasures as well as they also have a longing for the soul to God who elevates the high degree of man. fifth, morally positive, that is, Islam does not let people who have been decorated with Islamic morals follow social trends, walk the current, or are weak and give up facing events that control their lives. Islamic morals advocate to gather strength, struggle, and continue to do business with confidence and mind, against helplessness and pessimism (decisions), lazy and all forms of causes of weakness. He said, "Take it with the truth."

Islam rejects passive attitudes (apathy) in the face of social and political damage, moral and religious decadents, even Islam commands Muslims to change an evil with his "hands", if he is not able then with his oral, if he is not able then with his heart. Sixth, comprehensive, that is, if some people think that morals in religion revolve around the implementation of ritual worship, ceremonial and so on, then this is not exactly predicted on the ethics / morals in Islam, because Islamic ethics do not allow human activities only in worship alone. Islam has described a moral concept with a certain worship, even underlining the relationship of man with himself and his relationship with his people, so that Islamic morals include human relationship with nature globally as well as detail and for that Islamic morals put what human beings stand for from the high moral adab and the seventh noble teaching, tawazun (balance), that is, among the moral characteristics of Islam is Tawazun that combines something with harmony and harmony, without excessive attitude or reduction. Examples of tawazun are; a balanced attitude between the right of the body and the right of the spirit, so that there is no abuse of the body or the neglect of the spirit. Other examples are; balanced attitude in the "pursuit" of the world and the hereafter. Islam considers this a field for the Hereafter, and Allah has made mankind the caliph of the earth. The Word of God in al-Baqarah: 201. 
"And among them and those who pray: "Our Lord, grant us good in this world and good in the Hereafter, and protect us from the torment of the Fire." It is they who shall have a part of what they earn; and Allah is swift in reckoning."

Especially for local wisdom can be attributed to the fifth and sixth points of moral character in which that Islam does not let go of people who have been decorated with Islamic morals will follow social trends, walk the current, or be weak and give up facing events that control their lives. Islamic morals advocate to gather strength, struggle and continue the charity of effort with full confidence and mind, against the attitude of helplessness and pessimism (decisions), lazy, and all forms of causes of weakness, said Allah:

"Take the Book with earnest (full force)."

Islam rejects passive attitudes (apathy) in the face of social and political damage, moral and religious decadents, even Islam commands Muslims to change an evil with "his hands", if not able then with his "oral", if he is not able then with his "heart". The next comprehensive step, if some people think that morals in religion revolve around the implementation of ritual, ceremonial and so on, then this is not appropriate to predict to the ethics / morals in Islam, because Islamic ethics do not allow human activities only limited in worship. Islam has described a moral concept with a certain worship, even underlining human relationship with itself and its relationship with its people, then Islamic morals include human relationship with nature globally as well as detail and for that Islamic morals put what man wants from high moral adab and noble teachings.

In Islam talking about human behavior is "habit" or "customs". What is meant by "habit" is an act that is always repeated so that it becomes easy to do. We live in a diverse culture, it is so bad if the local culture and even the culture of this nation has a value of unity that should be upheld as well as possible. Especially if the culture brings strength, robustness, and solidarity among muslims. Because it is in harmony with Islam which means: "peace", Islam views the local culture proportionately, meaning that as long as the culture is not contrary to the norms and teachings of Islam itself.

In the world of Islamic jurisprudentship know the term 'urf i.e., the customs that makruf (already known) somewhere, which is typical, and related to local benefit. The strength of Islam is in its ability to adapt to previous cultures, and align that culture with Islamic values.

One element of local wisdom is good behavior, so in Islam do good and prevent bad deeds are found in the Qur'an and Hadith in HR. Muslim.
"And let there be among you a party that calls to virtue, enhorses the good, and forbids evil. They are the successful" (Ali Imran:104).

In the Hadith of HR. Muslim

"He who among you sees evil, let him change it with his hand, if he cannot then with his tongue, if he cannot then with his heart, and that is as weak as faith."

Local wisdom can be a color in Islam preaching. The existence of local wisdom is not to be eradicated, on the contrary it can be understood its strategic strength, and empowered. Because in local wisdom there are traces of our identity in the past. There is a history and noble values contained in local wisdom (customs and complexit).

\section{CONCLUSION}

That Islam is very appreciative of local wisdom, for Islam local wisdom is a forum in doing da'wah, so that Islam will be easily acceptable to the community with a variety of daily behaviors carried out repeatedly. Islam has come to be a filter against a synergism between local culture and outside culture. So that local wisdom will be able to grow and develop in accordance with the teachings of Islam in the daily behavior of local people.

A human civilization is born from a culture formed from the behavior of everyday people that is carried out repeatedly in the form of local wisdom. Civilization is a syntheses konvigeransi of culture formed from local wisdom. Islam makes local wisdom as a form of civilization of human beings. Islam becomes a filter of local wisdom in the majority Muslim country of Indonesia. So That Islam itself will be one of the filtering as well as the development of a birth of human civilization.

\section{REFERENCE}

Ahmad Baedowi (2 maret 2015). "Calak Edu: Esaiesai Pendidikan 2012-2014". Pustaka Alvabet.hlm.61.ISBN 978-602-9193-657.Diakses tanggal 2 April 2016.

Arif, Mahmud. (2015). Islam, Kearifan Lokal, dan Kontekstualisasi Pendidikan: Kelenturan, Signifikansi, dan Implikasi Edukatifnya. AlTahrir: Jurnal Pemikiran Islam, 15(1), 67-90.

Al-Qardhawy, Yusuf. (1997). Fiqih Daulah; Dalam Perspektif Al-Qur'an dan Sunnah. Diterjemahkan Oleh Kathur Suhardi. Jakarta: Pustaka Al-Kautsar.

A.S.Padmanugraha,"Common Sense Outlook on Local Wisdom and Identity:A Contemporary Javanese Natives' Experience' Paper Presented in International Conference on "Local Wisdom for Character Building",(Yogyakarta:2010). HIm.12. 
As‘ad El Hafidy, Muh. (1982). Aliran-aliran kepercayaan dan kebatinan di Indonesia. Ghalia Indonesia

Indonesia, Republik. (1959). Undang-Undang Dasar 1945. Dewan Pimpinan PNI, Department Pen. Prop. Pen. Kader.

Indrawardana, Ira. (2012). Kearifan lokal adat masyarakat Sunda dalam hubungan dengan lingkungan alam. Komunitas: International Journal of Indonesian Society And Culture, 4(1)

Lamijan, "Etika dan Moral Dalam Pembelajaran", Tim Fasilitator PEKERTI dan AA Kopertis Wilayah VI Jawa Tengah, Salatiga,10-14 Juni 2013.

Muhammad Amin Syukur,MA, "Ensiklopedia Nabi Muhammad SAW Sebagai Pendidik.", PT Ikrar Mandiriabadi,Jakarta. HIm VI.

Muhammad Amin Syukur,MA, "Ensiklopedia Nabi Muhammad SAW Dalam Ragam Gaya Hidup 1 ., PT Ikrar Mandiriabadi,Jakarta. HIm Viii.

Morley, Louise, \& Ife, Jim. (2002). Social work and a love of humanity. Australian Social Work,
55(1), 69-77.

Pusat Pembinaan Agama (PPA) Universitas Brawijaya.

Rahyono, F. (2009). Cultural Wisdom in the Word. Jakarta: Wedatama Widya Sastra.

Sibarani, Robert. (2012). Kearifan lokal: hakikat, peran, dan metode tradisi lisan. Asosiasi Tradisi Lisan (ATL).

Triyadi, Sugeng, Sudradjat, Iwan, \& Harapan, Andi. (2010). Kearifan Lokal Pada Bangunan Rumah Vernakular Di Bengkulu Dalam Merespon Gempa Studi Kasus: Rumah Vernakular di Desa Duku Ulu. Local Wisdom: Jurnal IImiah Kajian Kearifan Lokal, 2(1), 1-7.

Syekh Hafizh Hakami, "Tanya Jawab Akidah Islam", Gema Insani Press, Jakarta 1998.

Thohir Luth,dkk, "Pendidikan Agama Islam”, Buku Daras, Universitas Brawijaya.

Thohir, Ajid. (2009). Perkembangan Peradaban di Kawasan Dunia Islam (Vol. 1). RajaGrafindo Persada. 